\title{
The Use of the Vernacular in Early Modern Philosophy
}

\author{
Wiep van Bunge
}

\section{Hegel to Copleston}

Few modern philosophers have determined our understanding of early modern philosophy in the way Hegel has. More in particular, Hegel held highly influential views on the real significance of the language in which philosophy came into its own after the Middle Ages. In his Lectures on the History of Philosophy Hegel introduced the issue in his paragraph on Luther, who completed his Reformation of Christianity, or so Hegel argued, by rendering the Bible into German, for according to Hegel philosophical self-consciousness can only be achieved in a native language, a language, that is, we can truly call our own. For, Hegel continued, only a language that is able to express our innermost concerns can serve as a vehicle for our subjectivity:

In der Sprache ist der Mensch produzierend: es ist die erste Äusserlichkeit, die der Mensch sich gibt durch die Sprache; es ist die erste, einfachste Form der Produktion, des Daseins, zu der er kommt im Bewusstsein; was der Mensch sich vorstellt, stellt er sich auch innerlich vor als gesprochen. Diese erste Form ist ein Gebrochenes, Fremdartiges, wenn der Mensch in einer fremden Sprache sich ausdrücken oder empfinden soll, was sein höchstes Interesse berührt. Dieser Bruch mit dem ersten Heraustreten in das Bewusstsein ist so aufgehoben; hier bei sich selbst in seinem Eigentum zu zein, in seiner Sprache zu sprechen, zu denken, gehört ebenso zur Form der Befreiung. Dies ist von unendlicher Wichtigkeit. Luther hätte nicht seine Reformation vollendet, ohne die Bibel ins Deutsch zu übersetzen; und nicht ohne diese Form, in eigener Sprache zu denken, hätte die subjektive Freiheit bestehen können. ${ }^{1}$

According to Hegel, Luther constitutes such a pivotal moment in the history of Geist or Spirit, since the Reformation first affirmed the principle of

$1 \quad$ Hegel, Werke xx, pp. 52-53. 
self-consciousness - and this principle, Hegel felt, was the very principle of modern philosophy itself. ${ }^{2}$ While this early nineteenth-century conception of the rise of modern philosophy entails a highly normative conception of what philosophy really is, its insistence on the crucial dependence of genuine philosophical reflection on the vernacular served until recently as a standard ingredient of scholarly descriptions of the incipience of modern philosophy.

Consider, for example, the way in which Frederick Copleston introduced the fourth volume, on Descartes to Leibniz, of his monumental History of Philosophy:

whereas the mediaevals wrote in Latin, in the post-mediaeval period, we find an increasing use of the vernacular. It would not, indeed, be true to say that no use was made of Latin in the pre-Kantian modern period. Both Francis Bacon and Descartes wrote in Latin as well as in the vernacular. So too did Hobbes. And Spinoza composed his works in Latin. But Locke wrote in English, and in the eighteenth century we find a common use of the vernacular. Hume wrote in English, Voltaire and Rousseau in French, Kant in German. ${ }^{3}$

Indeed, many sixteenth- and seventeenth-century names could be added, including Machiavelli and Bruno, Montaigne and Charron, Robert Hooke, Anne Conway and Sir Kenelm Digby, as well as Pascal, Malebranche, Jean Du Hamel, Pierre Bayle, Fénelon and Fontenelle. All this will be pretty familiar, as will be Copleston's subsequent observation that the rise of the vernacular in early modern philosophy was closely related to the rapidly changing position in society of the philosopher: unlike their medieval predecessors, they, or to be more precise: the philosophers who made it to handbooks such as Copleston's, were no longer employed as university professors. Bacon was a lawyer and a politician, Descartes a nobleman of independent means, Hobbes served as tutor and secretary to the Cavendish family, Spinoza was an optician who even refused a chair in Heidelberg, Locke was a physician, Leibniz a diplomat and a librarian, Berkeley a bishop, and so on. As a consequence, they were no longer bound by the conventions ruling academic scholarship, the main one being of course the use of Latin.

2 Ibid., p. 63.

3 Copleston, A History of Philosophy IV, p. 16. 


\section{Recent Revisionism}

Over the past few decades a lot of energy has been invested in dismantling this picture, according to which the rise of early modern philosophy: a) was expressed in the vernacular, and b) took place outside the universities, and I should now like to sketch six objections that could be made to it, most of them inspired by recent research, after which I hope to be in a position to assess its tenability. First, as Copleston himself observed already, Bacon, Descartes, Hobbes and Spinoza still used Latin-Spinoza even exclusively so, the single text of his that has survived in Dutch, the Korte Verhandeling, being a translation made by his Amsterdam friends. ${ }^{4}$ To his considerable chagrin, even Locke was quickly identified as the author of the anonymous Epistola de tolerantia, published at Gouda in 1689. Leibniz and Newton also wrote much of their work in Latin, as did Kant for that matter, for not only were Kant's socalled 'pre-critical' works in Latin, from 1796 to 1798 Friedrich Gottlob Born issued a translation in four volumes, entitled Opera ad philosophiam criticam. ${ }^{5}$ In some cases the success a philosophical work enjoyed was solely due to its Latin translation: Campanella's La Città del sole was largely ignored until the author himself produced a version in Latin. ${ }^{6}$ When Descartes in 1619 met Isaac Beeckman at Breda, the future author of the Discours sur la méthode was only able to communicate with Beeckman because both men spoke Latin. ${ }^{7}$ But also among the so-called minor authors of the age, dozens could be referred to who still published many of their most important works in Latin, including Marin Mersenne, Pierre Gassendi, Nicolas Malebranche, John Toland, Samuel Pufendorf, Christian Thomasius and Christian Wolff. What is more, not all seventeenth and eighteenth-century university professors felt obliged to publish exclusively in Latin: Galileo, Antoine Arnauld, Henry More and Ralph Cudworth all held important academic positions (only More, a Cambridge Fellow, never made it to a professorial chair, although he became prebend), and they all published primarily in their native languages.

Neither does it appear to have been the case that the vernacular held any privileged position in proto-Enlightenment 'liberating' circles bent on castigating Christian 'prejudice': it is not as if the most 'emancipatory' thinkers opted for the vernacular out of principle. On the contrary, several of the most daring products of the early radical Enlightenment, including several

\footnotetext{
4 Spinoza, Korte Verhandeling, pp. 71-80.

5 Immanuelis Kantii Opera.

6 Waquet, Latin, or the Empire of a Sign, p. 87.

7 Ibid., p. 154.
} 
anonymous clandestine manuscripts, were composed in Latin, as were for example, the Origo et fundamenta religionis Christianae, the Theophrastus redivivus, the Symbolum Sapientiae, the De vera religionis inventione et forma, the Jordanus Bruno redivivus as well as Friedrich Wilhelm Stosch' Concordia rationis et fidei and Theodor Ludwig Lau's Meditationes philosophicae. ${ }^{8}$ Spinoza expressly forbade his friend to issue a Dutch translation of his hotly contested Tractatus theologico-politicus. ${ }^{9}$

Second, over the past few decades our understanding of the history of the early modern university has been increased dramatically, and few intellectual historians today will be prepared to be as dismissive of the academic practice of philosophy as was long customary. ${ }^{10}$ In particular the significance of universities for what is still, reluctantly, termed 'the scientific revolution' has been reassessed fundamentally, leading the late great Roy Porter to conclude that although Galileo quit his chair at Padua in 1610 and Newton left Cambridge in 1696 to become Master of the Mint, 'a remarkably high proportion of the great names of early modern science actually made their career (or at least embarked upon their career) as professors in university employment."11 Moreover, the very domains which were transformed most fundamentally during the seventeenth century belonged to the core curriculum of the studium generale taught by the artes faculty, and by the end of the seventeenth century the gap which traditionally had separated natural philosophy from mathematics was beginning to close, especially in France and the Netherlands-arguably on account of the success of Cartesianism. And while the scientific importance of the medical research being done at Padua, Montpellier, Leyden, Oxford and Cambridge has been recognized for quite some time now, there is also considerable evidence suggesting that mathematics played a much larger role in many of the more prominent universities of the early modern age than academic statutes would seem to convey.

In addition, we should not overestimate the hostility among seventeenthcentury 'novatores' such as Descartes and Hobbes toward the early modern university; Descartes was very concerned to have his views taught at Utrecht,

8 Schröder, Ursprünge des Atheismus, Appendix.

$9 \quad$ Spinoza, The Letters, p. 243.

10 For a survey, see De Ridder-Symoens (ed.), Universities in the Middle Ages and idem (ed.), Universities in Early Modern Europe.

11 Porter, 'The Scientific Revolution and Universities'. See also, for instance, Gascoigne, 'A Reappraisal'; Ruestow, Physics at Seventeenth and Eighteenth-Century Leiden; Feingold, The Mathematician's Apprenticeship; Brockliss, French Higher Education; Wallace, Galileo and his Sources; Vanpaemel, Echo's van een wetenschappelijke revolutie. 
Leyden as well as the Sorbonne and made sure to have his work translated into Latin as soon as possible; Hobbes, a major classicist in his own right, seriously felt his Leviathan would make for a fine course in Oxford. ${ }^{12}$ Gassendi was a professor at the Collège Royal, Pierre Bayle held a chair at the Rotterdam Illustrious School—not very impressive perhaps, and he refused an offer from Franeker University, but it would seem that all German Cartesians were indeed professors, and one expert recently characterised philosophy in seventeenthcentury Germany as 'overwhelmingly academic.'13 And while it is true that the national societies, set up in France, Britain and Prussia for the advancement of science beyond the confines of the university, promoted the vernacular, as is evident from the publication of the Philosophical Transactions of the Royal Society and from the decision of the Prussian Academy in 1745 to exchange Latin for French, both the Philosophical Transactions and the Journal des Savans were swiftly translated into Latin. The important German scientific journal Acta Eruditorum ran, exclusively in Latin, from 1682 to 1782 . The use of Latin in scholarly correspondence remained popular until well into the eighteenth century. Françoise Waquet wrote her study on the continuing relevance of Latin from the sixteenth to the twentieth centuries after she had completed her book, co-written with Hans Bots, on the eighteenth-century Republic of Letters, in which the use of Latin remained a sign of distinction, of class if you will. 'Democratic' as this Republic may have been, it was of course inhabited only by people, mainly men, with a proper education. ${ }^{14}$

Third, many experts on early modern philosophy today have become very weary of presenting Descartes as the unique point of departure, the decisive step forward to modernity in the way Hegel, Copleston and the authors of countless other surveys of seventeenth-century thought have attempted to do. Instead, they have become acutely conscious of the continuity between Descartes and the Scholastic background Descartes himself professed to have obliterated. In fact, from Étienne Gilson to Jean-Luc Marion, Dennis Des Chene and Roger Ariew, a powerful scholarly tradition has arisen which has demonstrated the extent to which Descartes depended on the very Aristotelian

12 Verbeek, Descartes and the Dutch; Serjeantson, 'Hobbes, the Universities and the History of Philosophy'.

13 Hunter, 'The University Professor in Early Modern Germany'. On Gassendi, see below, on Bayle: Bost, Pierre Bayle; on German Cartesianism: Trevisani, Descartes in Germania.

14 Bots and Waquet, La République des lettres, esp. pp. 146-148. See also Goldgar, Impolite Learning. 
natural philosophy he claimed to have destroyed once and for all. ${ }^{15}$ Over the past few decades, early modern Aristotelianism has made a particularly robust comeback on the scholarly agenda of historians of philosophy both in England and the United States and on the European Continent. ${ }^{16}$ The result is that since also Spinoza has been studied from that point of view recently, no major seventeenth-century philosopher before Locke has now not been commented upon at length from a Peripatetic perspective. ${ }^{17}$

More in general, today the recognition of the continuing popularity of the competing classical schools of thought such as Stoicism, Epicureanism, and of course Scepticism or Pyrrhonism during the early modern age is widely shared among historians of philosophy. ${ }^{18}$ And while the fate of Platonism following the Italian quattrocento is far less well documented, ${ }^{19}$ a fascinating phenomenon like the seventeenth-century 'Cambridge Platonists' demonstrates that even an almost obsessive preoccupation with the wisdom of the Ancients did not have to imply a preference for the use of Latin: as noted, both Henry More and Ralph Cudworth wrote their most important treatises in English.

Fourth, it might be worthwhile to pause and reflect on the use of language in the school of thought which traditionally has been regarded as the terminus ad quem of early modern philosophy, namely German Idealism, for its particular use of the German language has always given rise to comments. In particular Kant's Kritik der reinen Vernunft is heavy with such a peculiar terminology of Kant's own making that many of its first readers were baffled by its idiom. Translating Kant's 'transcendental' philosophy into other native languages turned out to be no easy feat: the Dutch Kantian Paulus van Hemert was chastised by his contemporary critics for the highly peculiar 'Dutch' he used-Van

15 See most notably Gilson, Études sur le rôle de la pensée médiévale; Marion, Sur le prisme métaphysique de Descartes; Des Chene, Physiologia; Ariew, Descartes and the Last Scholastics.

16 Randall, The School of Padua; Schmitt, Aristotle and the Renaissance; Mercer, 'The Vitality and Importance of Early Modern Aristotelianism'; Grant, The Foundations of Modern Science; Di Liscia, Kessler and Methuen (eds.), Method and Order in Renaissance Philosophy of Nature; Blackwell and Kusukawa (eds.), Philosophy in the Sixteenth and Seventeenth Centuries; Ariew and Gabey, 'The Scholastic Background'.

17 See for instance Schuhmann, 'Hobbes and Renaissance Philosophy'; Leijenhorst, The Mechanization of Aristotelianism; Mercer, Leibniz's Metaphysics; Osler, Divine Will and the Mechanical Philosophy as well as several of the essays presented in Sorell (ed.), The Rise of Modern Philosophy and Manzini, Spinoza.

18 See for instance Popkin, The History of Scepticism; Schmitt, Cicero Scepticus; Oestreich, Neostoicism and the Early Modern State; Wilson, Epicureanism at the Origins of Modernity.

19 See, however, Hedley and Hutton (eds.), Platonism at the Origins of Modernity. 
Hemert actually invented many new words in order to bring home Kant's 'critical' philosophy. ${ }^{20}$ Early nineteenth-century critics of Kant accused him of having reinstalled just another variant of Scholasticism-not unlike the way in which some twentieth-century philosophers have come to regard the tradition of what for want of a better word is still referred to as 'analytical philosophy'.

This brings me to a fifth objection: is it really true that medieval philosophy was exclusively scholastic, that is put into the Latin we associate with Aquinas, Duns Scotus and William of Ockham? Or is it possible to identify philosophical traditions in the vernacular before, say: Machiavelli? According to Ruedi Imbach it most certainly is, for two reasons in particular: on the one hand, well before the end of the fourteenth century several key texts in philosophy had been translated into the native languages of Europe: Boethius' De consolatione philosophiae, for instance, by 1400 was available in fourteen different versions in French alone. ${ }^{21}$ On the other hand, Imbach has identified 'lay' authors active during the High Middle Ages, including many who had little use for Latin, including (the unfortunately named) Brunetto Latini, to whom many examples could be added from the tradition I know best: the Dutch. ${ }^{22}$

As early as 1267 Jacob van Maerlant wrote 'scholastica willic ontbinden. In dietsche wort uten latine' ('I wish to liberate scholasticism from its Latin shackles and render it in Dutch'). ${ }^{23}$ Closely associated with the court of Floris $\mathrm{v}$, count of Holland, Van Maerlant produced a remarkable series of philosophical translations, including the popular pseudo-Aristotelian Secreta secretorum as well as an encyclopaedia on the wonders of Nature and a dialogue on a wide variety of ethical subjects - all in Dutch, or 'Dietsch' as Van Maerlant would have it. Thus, he created a philosophical vocabulary in the vernacular which around 1400 was further developed by Dirc van Delft and by the many contemporary translations made of the writings of Geert Grote and the other members of the devotio moderna. Consequently, at the dawn of the early modern

20 One of the most vociferous critics of Van Hemert was the Amsterdam and Leiden professor Daniel Wyttenbach, who was a born Swiss and who still published exclusively in Latin: Von Prantl, 'Daniel Wyttenbach als Gegner Kants'. On the early Dutch reception of Kantianism, see more recently Van Hemert, Gezag en grenzen van de menselijke rede; Wielema, 'Die erste niederländische Kant-Rezeption'; Hanou, Sluiers van Isis; Onnasch, 'De eerste receptie van Kants filosofie in Nederland'; Franke, Een gedeelde wereld?, Chapter 3 .

21 Imbach, Laien in der Philosophie des Mittelalters, pp. 43-52.

22 Ibid., pp. 53-66.

23 Krop, 'De wijsbegeerte en het Nederlands', p. 82. This article has been a great help in the preparation of this lecture. See also Nitschik, Das volkssprachliche Naturbuch; Van Oostrom, Maerlants wereld. 
age even such minor provinces of the Holy Roman Empire as the Netherlands had a pretty elaborate philosophical vocabulary at their disposal.

Finally, and arguably most importantly, the Hegelian vision according to which no genuinely innovative work in philosophy could be done before Descartes identified the subject as the locus from which the Spirit could unfold itself and thus put the wheel in motion toward its ultimate self-discovery, hinges on the presupposition that the Renaissance, as Jacob Burckhardt put it in his seminal Die Cultur der Renaissance in Italien, did not produce any original philosophy of its own. ${ }^{24}$ Now as a matter of fact, possibly the greatest twentieth-century scholar of Renaissance humanism basically agreed, for according to Paul Oskar Kristeller Renaissance humanism as a professional endeavour did not really include philosophy:

Much of the work of leading humanists and all of the work of many minor humanists has no significance whatsoever for philosophy in any sense of the term but only for scholarship and literature. Vice versa, much of the philosophical literature of the Renaissance was not due to the humanists, but to Aristotelian philosophers with a scholastic training, to Platonist metaphysicians influenced by both humanism and scholasticism and above all by Plato and Neoplatonists such as Ficino and his followers, or to original thinkers, marginally influenced by humanism, from Nicholas of Cusa down to Telesio, Bruno and Francis Bacon. ${ }^{25}$

Two observations seem in place: first, it could be argued that, from an early modern perspective, it was hardly self-evident that philosophy should be original or innovative at all. Indeed, Descartes and his first supporters were actually accused of wanting to introduce all sorts of 'novelties'. Why, many seventeenthcentury thinkers still felt, should we be at all committed to change let alone abandon Aristotelianism? As a highly flexible, universally applicable conceptual vocabulary, it served to articulate our common-sense experience of the world we live in. It is not as if Descartes had established its deficiencies. He merely presented an alternative view of the world that incidentally made the universe look very odd indeed and very different from the way we experience it to be. ${ }^{26}$ By the middle of the seventeenth century it remained very much to

\footnotetext{
24 Burkhardt, Die Cultur der Renaissance in Italien. This view was criticised already by Cassirer, Individuum und Kosmos.

25 Kristeller, 'Humanism', pp. 133-134.

26 Van Ruler, The Crisis of Causality; Verbeek, 'Dutch Cartesian Philosophy'.
} 
be seen whether Descartes' vision of philosophy as a project of future enquiry, in which the use of Latin was no longer self-evident, would actually prevail.

Second, several prominent, more recent specialists on Humanism, that is on the intellectual movement flowering between the death of William of Ockham in 1347 and the publication of Descartes' works in the 1640s, have been pretty successful in demonstrating that from Lorenzo Valla onward, 'humanist' thinkers had a far more profound effect on philosophy and theology for that matter than Burckhardt's and Kristeller's views allowed for. ${ }^{27}$ The Dutch historian of philosophy Lodi Nauta has recently made an impressive attempt to turn Valla into a genuine precursor of 'ordinary language philosophy'. ${ }^{28}$

Still, humanist authors excelled at nothing as much as they did in writing Latin, although it was precisely their linguistic acumen that also enabled them to produce important translations, empowering philosophical discourse beyond the confines of the university throughout Europe-consider, to name just one, particularly illuminating example Jill Kraye's paper on Thomas Gataker's rendering into English of Marcus Aurelius' Meditations: among classicists, Gataker's translation from $165^{2}$ still stands as a marvel of scholarship, yet by historians of philosophy it has been ignored completely. ${ }^{29}$ And not all humanists preferred Latin: from Montaigne through Bayle right up to Vico, a powerful tradition of profound, 'humanist' erudition expressed in the vernacular established a connection between 'humanist' scholarship and cutting-edge philosophical analysis, turning, if you will, 'the Renaissance' into the natural cradle of 'the Enlightenment'.

\section{Hegel Vindicated}

It would seem, then, when all is said and done, that the Hegelian point of view on the rise of the vernacular in philosophy as a token of its budding modernity stands in need of urgent qualification. Or should we, perhaps, abandon it altogether? I think not: for despite our increased awareness of the continuities between the 'old' and 'new' philosophies in the early modern age, and despite the evident connections between 'lay' philosophers opting for the vernacular and professional academics communicating exclusively in Latin, this did

27 See for instance the essays collected in Kraye and Stone (eds.), Humanism and Early Modern Philosophy. Antony Grafton's justly famous collection of essays entitled Defenders of the Text has little to offer on Philosophy. See, however, Gaukroger, Francis Bacon.

28 Nauta, In Defense of Common Sense.

29 Kraye, “"Ethnicorum omnium sancticissimus.” 
not alter the fact that Latin was a dead language. As such, it could only be resuscitated at the expense of its purity. Moreover, the seventeenth century in particular witnessed a profound shift in 'paradigm' if you will: in natural philosophy as well as in metaphysics, from cosmography to the definition of matter and the explanation of change and motion, there is simply a world of difference between, say the Cambridge Platonists and their contemporary John Locke, and not the least of these changes directly concerns the use of the vernacular. Whereas More and Cudworth were still inspired by the vision of an 'Ancient Wisdom', an essentially timeless prisca sapientia, by contrast Locke's conception of philosophy as the task of what he called 'an Underlabourer' is completely oriented toward the future elucidation of issues concerning theory of knowledge. When natural philosophy, which during the sixteenth and seventeenth centuries had still served as the major arena in which the great battle between 'old' and 'new' conceptions of philosophy had been raging, grew into natural science, epistemology became the chief concern of philosophy, but as such it remained closely associated with the latest developments in physics in particular. Thus, the relevance of classical philosophy gradually evaporated as did the use for Latin. As Peter Burke has pointed out, of the over 500 early modern translations from the vernacular into Latin that have been identified by him a mere 18 titles belong to philosophy. ${ }^{30}$

What is more, if we take a closer look at for instance the Dutch example, which I just happen to be most familiar with, it simply cannot be denied that from the early nineteenth century onward the use of Latin in philosophy became very rare indeed. Although Dutch was a relatively young language, it had a considerable philosophical tradition that was closely related to its codification. Only by the second half of the sixteenth century, at a time when the Southern Netherlands had turned into a very wealthy province of the Spanish empire and the Dutch Revolt was about to launch the Dutch Republic as a sovereign state, did the codification of the Dutch language get under way. The first Dutch grammar was published in 1564, probably by Dirk Volkertsz. Coornhert, a personal friend of William of Orange and the author as well of the first Dutch Ethics in the vernacular, entitled Zedekunst (1586). Recent research has established, however, that Coornhert stood in a considerable literary tradition of moral reflection in the Dutch language, which may perhaps help to explain the stunning self-consciousness of a host of humanist scholars active around 1600 and arguing with great zeal for the exceptional excellence of the Dutch

30 Burke, 'Translation into Latin in Early Modern Europe'. See also Grant, 'European Vernacular Works in Latin Translation'. 
language. ${ }^{31}$ The Antwerp scholar and personal physician to Philip II (who according to Venetian diplomats 'spoke Latin quite well, for a prince'), ${ }^{32}$ Johannes Becanus, went to considerable lengths in order to demonstrate that it was in reality the language spoken by Adam and Eve. ${ }^{33}$

During the seventeenth century the rapidly increasing importance of Dutch in philosophy is evident not only from the many excellent translations produced both of Frank Burgersdijk's Aristotelian handbooks and of the writings of Descartes and Spinoza. ${ }^{34}$ For in addition radical Cartesians such as Lodewijk Meyer and Adriaan Koerbagh also composed highly interesting dictionaries, explicitly aimed at 'enlightening' the common man. ${ }^{35}$ Adriaan Koerbagh, who died in jail in Amsterdam in 1669, having been prosecuted for 'atheism', articulated what could perhaps be called a 'political linguistics', according to which Latin had essentially become a power tool in the hands of the legal as well as the clerical 'professions', creating an ignorant and therefore powerless 'clientele' of people who had simply been unable to afford a university education.

Although the Radical Enlightenment envisaged by Meyer and Koerbagh failed to make a lasting impact on the Dutch Republic, the abundant availability in the vernacular of 'new' and potentially revolutionary philosophical texts around 1700 gave rise to a very lively philosophical culture-all sorts of laymen, some of them female, with little or no Latin at all now felt able and entitled to take part in highly obtuse metaphysical disputes concerning the nature of God, the essence of the soul and the definition of matter. ${ }^{36}$ When the Amsterdam minister Balthasar Bekker launched his broadly Cartesian attack on belief in witchcraft and sorcery, entitled De betoverde Weereld (1691-93), dozens of amateur philosophers and theologians joined the fray. ${ }^{37}$ By this time, Dutch professors of philosophy and theology no longer felt inhibited either to cross swords with laymen in Dutch.

31 Buys, De kunst van het weldenken. See also Bange, Moraliteyt saelt wesen.

32 Waquet, Latin, or the Empire of a Sign, p. 154.

33 Van Hal, 'Moedertalen en taalmoeders', pp. 83-136.

34 Dibbets, 'Kóks Burgersdijkvertalingen'; Thijssen-Schoute, 'Jan Hendrik Glazemaker'; Akkerman, Studies in the Posthumous Works of Spinoza, Chapter 5.

35 Israel, Radical Enlightenment, Chapters 10 and 11; Den Boer, 'Le Dictionnaire libertin d'Adriaen Koerbagh'; Koerbagh, A Light Shining in Dark Places. The relevant literature on Meyer and Koerbagh and many other minor Dutch authors of the time can be found in Van Bunge et al. (eds.), Dictionary.

36 Israel, Radical Enlightenment, passim; Wielema, The March of the Libertines.

37 Fix, Fallen Angels; Van Bunge, From Stevin to Spinoza, Chapter 5; Israel, Radical Enlightenment, Chapter 21. 
During the eighteenth century Dutch philosophers would continue to publish in their native language although in the siècle des Lumières another second language quickly became increasingly important: when Latin did start to give way several prominent Dutch authors such as Justus van Effen, Belle van Zuylen and Frans Hemsterhuis wrote largely and in Van Zuylen's and Hemsterhuis' cases exclusively in French. The second half of the eighteenth century witnessed yet another flowering of Dutch philosophical literature, this time of a largely political nature, but from a European perspective the efforts of these late eighteenth-century authors mattered little if only since they were essentially concerned to diagnose the sorry state of the Dutch Republic itself. But it's true that Dutch Enlightenment discourse was almost univocally in Dutch and intentionally so. Using Latin in philosophy beyond the academic classroom became, indeed, antiquated. ${ }^{38}$

Important as the late eighteenth-century may have been in relation to the ensuing creation of the Kingdom of the Netherlands, the inward-looking nature of its philosophical thought prevented it from rising above an essentially local relevance. ${ }^{39}$ Unfortunately, much the same must be said of Dutch nineteenth-century philosophy. Disappointing as the writings of for instance Philip Willem van Heusde and Cornelis Opzoomer may appear to us, their contemporary impact was considerable, not only within the Dutch universities, but in a very real sense they also served as public intellectuals. ${ }^{40}$ Although Dutch academic orations as well as dissertations continued to be in Latin until the middle of the nineteenth century, to all intents and purposes Opzoomer was delighted to be able to publish his findings in his native language. Perfectly in tune with the creation, in 1813, of a new Kingdom of the Netherlands,and, I should add, the creation in 1797 at Leyden of the first chair for Dutch linguistics ${ }^{41}$ — the call for a genuinely 'Dutch' philosophy was ubiquitous. ${ }^{42}$

Thus it would seem that the final blow to the use of Latin in philosophy was delivered neither by scholarly, scientific or strictly philosophical developments, nor by the increasingly awkward fact that Latin was a dead language, the idiom of which had to be stretched constantly in order to fit a world packed with canons, steamships, and countless other objects Cicero could not have

$38 \quad$ Kloek and Mijnhardt, 1800 , esp. Chapters 13 and 19. See also Van Sas, De metamorfose van Nederland; Velema, Republicans.

39 De Quay, De genoegzaamheid van het natuurlijk gezond verstand, Chapter 6.

40 See Van Heusde, Wijsbegeerte van het gezonde verstand; Opzoomer, Het wezen der kennis.

41 Held by Matthijs Siegenbeek. See Noordegraaf, Norm, geest en geschiedenis; De Vries (ed.), 'Eene bedenkelijke nieuwigheid.' 
dreamt of, but by the rise of the nineteenth-century nation-state. It should be noted that Hegel's appreciation of the vernacular had been prepared in considerable detail by Fichte's Reden an die deutsche Nation (1808), delivered in Berlin during the French occupation. Only a living language Fichte had argued in his fourth address, which articulates the way in which a people actually experiences the world it inhabits is able to express a meaningful reflection of this very experience. Even single words that are 'foreign' to the German Language will inevitably evoke artificial sentiments. We know, Fichte claimed, what 'Menschlichkeit' means, but which ideas is a concept like 'Humanität' supposed to instil? ${ }^{43}$ Indeed, the continuing, unbroken and untainted vitality of the German language, Fichte concluded, will assure the German people of a glorious future, in particular in philosophy. Prefiguring not only Hegel, but also and more ominously Heidegger, Fichte felt that any future true philosophy would have to be German:

Die wahre, in sich selbst zu Ende gekommene und über die Erscheinung hinweg wahrhaft zum Kerne derselben durchgedrungene Philosophie hingegen geht aus von dem Einen, reinen, göttlichen Leben,- - als Leben schlechtweg, welches es auch in alle Ewigkeit, und darin immer Eines bleibt, nicht aber als von diesem oder jenem Leben; und sie sieht, wie lediglich in der Erscheinung dieses Leben unendlich fort sich schliesse und wiederum öffne, und erst diesem Gesetze zufolge es zu einem Seyn und zu einem Etwas überhaupt komme. Ihr entsteht das Seyn, was jene sich vorausgeben lässt. Und so ist denn diese Philosophie recht eigentlich nur deutsch, d. i. ursprünglich; und umgekehrt, so jemand nur ein wahrer Deutscher würde, so würde er nicht anders denn also philosophiren können. ${ }^{44}$

The political development of the rise of the nation-state largely coincided with the moment philosophy returned to the university - a university, moreover, that during the nineteenth century abandoned the use of Latin. After Kant most of the major philosophers once more were professors: from Kant to Hegel and from Hegel to Husserl and Heidegger, from Comte to Derrida and from Mill to Quine-even Nietzsche embarked on his career as an academic, and even Wittgenstein's return to philosophy took the shape of his return to Cambridge

43 Fichte, Sämtliche Werke viI, pp. 311-28.

44 Ibid., viI, p. 362 . On the Heidegger connection, see Sluga, Heidegger's Critics; Bambach, Heidegger's Roots; Rockmore, 'Fichte, Heidegger, and Nazis'. 
in 1929 (a few hours after Wittgenstein's arrival, John Maynard Keynes wrote a letter to friend, announcing 'God has arrived. I met him on the 5.15 train') ${ }^{45}$

\title{
Conclusion
}

In 1751, in his Discours préliminaire to the Encyclopédie, d'Alembert observed the gradual decline of Latin and 'l'usage de toute écrire aujourdhui en langue vulgaire.' While d'Alembert acknowledged the advantages of this for French philosophes, he was also weary of where this might lead to, for today, he continued, even Englishmen write in their native language and even in Germany Latin is losing ground. Soon 'Swedes, Danes and Russians' will opt for the vernacular:

\begin{abstract}
Ainsi avant la fin du XVIII ${ }^{\mathrm{e}}$ siècle, un philosophe qui voudra s'instruire à fond des découvertes de ses prédécesseurs, sera constraint de charger sa mémoire de sept à huit langues différentes; et après avoir consumé à les apprendre le temps le plus précieux de sa vie, il mourra avant de commencer à s'instruire. L'usage de la langue latine (...) ne pourrat être que très utile dans les ouvrages de philosophie, dont la clarté et la précision doivent faire tout le mérite, et qui n'ont besoin que d'une langue universelle et de convention. Il serait donc à souhaître qu'on rétablit cet usage: mail il n'y a pas lieu de l'esperer. ${ }^{46}$
\end{abstract}

Latin did not return, and d'Alembert knew full well that it wouldn't-not in philosophy, that is. In the 1770 , the French journalist Jacques Vincent Delacroix compared Latin to a house 'richement meublée, spacieuse et abandonee., ${ }^{47}$

Over the past few decades philosophy has once more become a discipline in which a single language has come to dominate. Today professional philosophers who were not born in an Anglophone country are again challenged by the necessity to express themselves and communicate in a foreign language. Although most of us continue to publish in English and in Dutch, many of us feel our Dutch papers and books do not really count—even when English and American colleagues exhort us not to abandon our native language, as did the members of the committee responsible for the most recent Research

\footnotetext{
45 Monk, Ludwig Wittgenstein, p. 255.

46 D'Alembert, Discours préliminaire, pp. 153-154.

47 Burke, 'Heu domine, adsunt Turcae', pp. 29-30.
} 
Assessment of Philosophy in the Netherlands. ${ }^{48}$ Perhaps the bilingualism of our early modern predecessors may carry some consolation, for it would seem that, in the end, it did not really matter that Montaigne and Descartes wrote in French, Spinoza and Newton in Latin, and Leibniz in both: they were all read and they are still being studied today. We have only just begun to seriously question the reasons why some early modern philosophers made it to the canon, while others didn't. ${ }^{49}$ Easy answers do not seem available, and canons evolve, but one could be forgiven to expect that in the long run, philosophers who opted for the vernacular did increase the accessibility of their writings: perhaps Gassendi could have made a bigger impact, had he not chosen to publish massive, intricate volumes such as his Disquisitio metaphysica of 1644. But then again, the beautiful and highly accessible English produced by eminent scholars such as Henry More and Ralph Cudworth could not ensure them a position in the Canon of European philosophy either. The fact that their work was also translated into Latin could not make any difference.

\footnotetext{
48 http://www.qanu.nl/comasy/uploadedfiles/philosophy_def.pdf, p. 13.

49 See, most recently Rogers, Sorell and Kraye (eds.), Insiders and Outsiders in SeventeenthCentury Philosophy.
} 